\title{
Local Seismic Events in the Area of Poland Based on Data from the PASSEQ 2006-2008 Experiment
}

\author{
Marcin POLKOWSKI ${ }^{1}$, Beata PLESIEWICZ ${ }^{2}$, Jan WISZNIOWSKI ${ }^{2}$, \\ Monika WILDE-PIÓRKO ${ }^{1}$, and PASSEQ Working Group \\ ${ }^{1}$ Institute of Geophysics, Faculty of Physics, University of Warsaw, \\ Warsaw, Poland; \\ e-mail: marcin.polkowski@igf.fuw.edu.pl (corresponding author) \\ ${ }^{2}$ Institute of Geophysics, Polish Academy of Sciences, Warsaw, Poland
}

\begin{abstract}
PASSEQ 2006-2008 (Passive Seismic Experiment in TESZ; WildePiórko et al. 2008) was the biggest passive seismic experiment carried out so far in the area of Central Europe (Poland, Germany, the Czech Republic and Lithuania). 196 seismic stations (including 49 broadband seismometers) worked simultaneously for over two years. During the experiment, multiple types of data recorders and seismometers were used, making the analysis more complex and time consuming. The dataset was unified and repaired to start the detection of local seismic events. Two different approaches for detection were applied for stations located in Poland. The first one used standard STA/LTA triggers (Carl Johnson's STA/LTA algorithm) and grid search to classify and locate the events. The result was manually verified. The second approach used Real Time Recurrent Network (RTRN) detection (Wiszniowski et al. 2014). Both methods gave similar results, showing four previously unknown seismic events located in the Gulf of Gdańsk area, situated in the southern Baltic Sea. In this paper we discuss both detection methods with their pros and cons (accuracy, efficiency, manual work required, scalability). We also show details of all detected and previously unknown events in the discussed area.
\end{abstract}

Key words: local seismicity, seismic detection methods, Poland.

Ownership: Institute of Geophysics, Polish Academy of Sciences

(C) 2016 Polkowski et al. This is an open access article distributed under the Creative Commons

Attribution-NonCommercial-NoDerivs license

http://creativecommons.org/licenses/by-nc-nd/3.0/. 


\section{INTRODUCTION}

\subsection{PASSEQ 2006-2008}

The Transeuropean Suture Zone (TESZ), which extends over $2000 \mathrm{~km}$ from Great Britain to the Black Sea, makes a contact zone between Eastern and Western Europe. The eastern border of the TESZ is defined by the Teisseyre-Tornquist Zone (TTZ), which runs across Poland. TTZ is a welldefined 50-100 km wide zone and delimits two tectonic units - the East European Craton and the Eastern and Paleozoic Platform of Western and

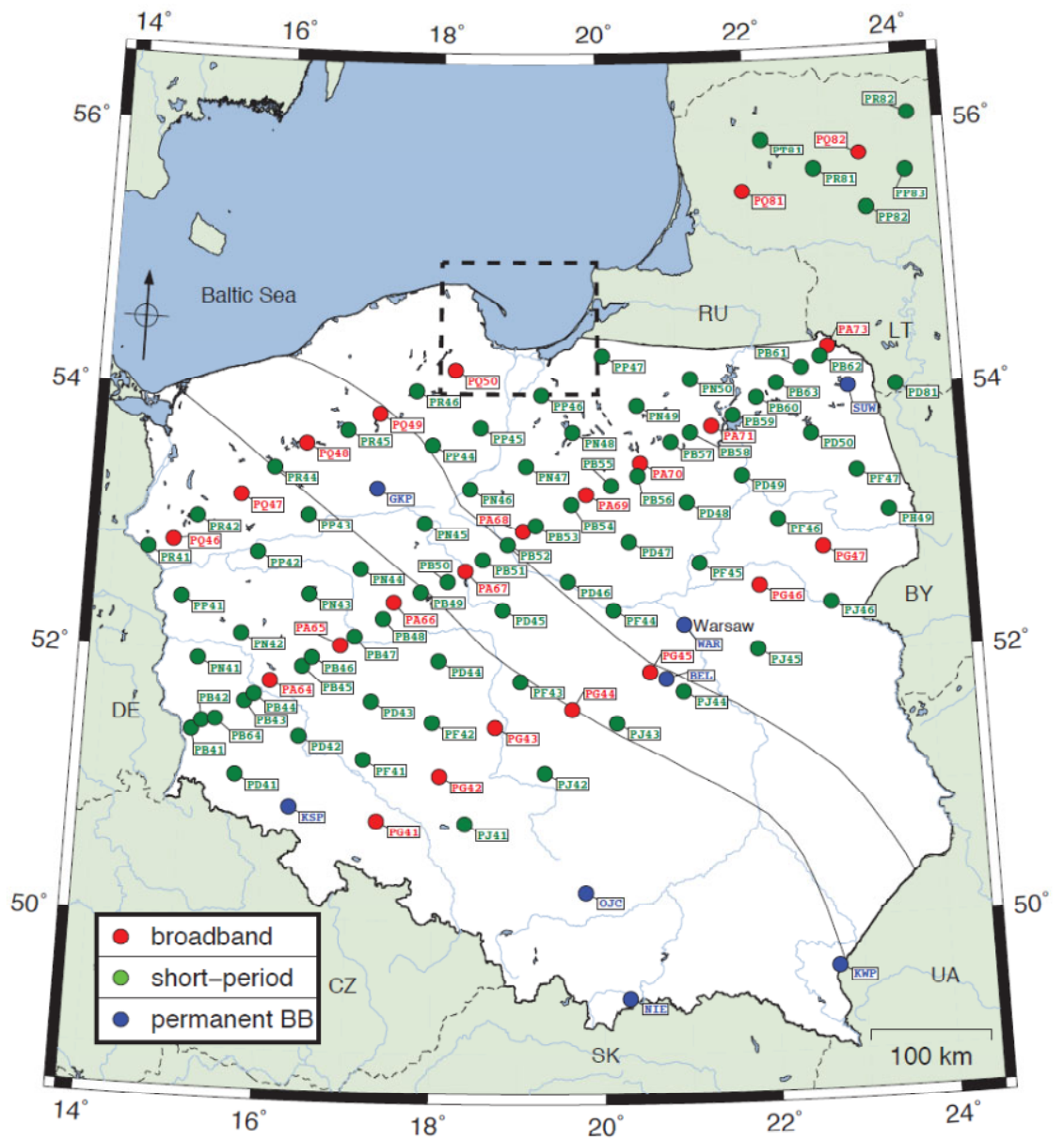

Fig. 1. Location map of PASSEQ 2006-2008 stations used in this study. PASSEQ stations are marked red (broadband) and green (short-period). Permanent stations of the Polish Seismological Network are marked blue. Two thin grey lines indicate the location of the Trans European Suture Zone. The thick dashed line marks the area shown in Fig. 9. 
Central Europe (Pharaoh 1999). The East European Craton crust next to TTZ in northeastern Poland is $42-47 \mathrm{~km}$ thick, while on the Paleozoic Platform sill of the crust, its depth is $28-34 \mathrm{~km}$ (Grad et al. 2009). We can find a great variety of lithosphere structures within Polish territory. Recognition of the TTZ deep lithosphere structure is crucial for understanding tectonic processes that are taking place in Central Europe.

The passive seismic experiment (called the Passive Seismic Experiment in the Trans European Suture Zone (PASSEQ)) was carried out from May 2006 till June 2008 (Wilde-Piórko et al. 2008). The goal of the project was to recognize deep lithospheric structures in the border zone of the Precambrian Platform in Northern and Eastern Europe, and the Paleozoic Platform in Central and Western Europe. The PASSEQ experiment was concentrated in the central part of TESZ. The PASSEQ experiment was supported by 17 participating scientific institutions from Europe and the United States.

A total of 147 three-component temporary short-period and 49 temporary broadband seismic stations were installed along about $1200 \mathrm{~km}$ of seismic profiles, which were used to investigate the structure of the crust and upper mantle in TESZ. The experiment included a $400 \mathrm{~km}$ wide array starting in Germany, through the Czech Republic, Poland and ending in Lithuania. The distances between the stations were about $60 \mathrm{~km}$, while in the longest central profile the distance was only about $20 \mathrm{~km}$ (Fig. 1) Moreover, the stations of the National Seismic Networks were also included. The stations were mainly located in forester shelters, castles, monasteries and small farms. The sampling frequency of the instruments was 20,50 or $100 \mathrm{~Hz}$. Finally, all seismic registrations were gathered on the GeoForschungsZentrum Potsdam (GFZ) servers in Potsdam (Germany), where they were exclusive data for 6 years. Since May 2014 these data are open for access and can be found on the GFZ website on request.

\subsection{Detection}

There are many methods of detection, which were classified into a few categories by Withers et al. (1998): methods working in the time domain, methods operating in the frequency domain, methods based on particle motion processing, and pattern matching methods. Detection in the time domain is based on an analysis of the changes of signal amplitude with time. Signal analysis can be performed separately for all signal components and different frequency bands. The simplest possible detection method is based on the amplitude threshold, but since it is extremely sensitive to noise, the commonly used methods involve relations between amplitude averages over moving time windows of different lengths (Allen 1978, 1982; Trnkoczy 2012). 
Event detections in the frequency domain are based on Fourier Transform (McEvilly and Majer 1982), band-pass filters (Evans and Allen 1983, Gledhill 1985), Walsh Transform (Goforth and Herrin 1981, Ebel 1996), and autoregressive coefficients (Tarvainen 1991). The pattern recognition methods (PR) (Joswig 1990, 1993) benefit from information both in the time and frequency domains, however it is quite difficult to prepare a good set of patterns.

Artificial neural networks (ANNs) were widely used for seismic event detection. ANNs are taught to detect events; therefore, they require the set of examples of events and noise. Most of ANN methods are based on feedforward multi-layer-perceptron (MLP) networks. The networks are fed by vectors of momentary parameters of the signal or by the moving window of one parameter. The moving window method (Wang and Teng 1995, 1997; Gentili and Michelini 2006) corresponds to detection in the time domain, whereas a network with a vector of temporal parameters on input corresponds to detection in the frequency domain (Wang and Teng 1995, Tiira 1999). Gentili and Michelini (2006), as well as Madureira and Ruano (2009) fed the ANN by a moving window of vectors. Another solution is to use a network with recurrent neurons (RN) (Williams and Zipser 1989, Elaman 1990) investigating momentary values in the frequency domain as well as any relationships in the time domain (Wiszniowski et al. 2014, Tiira 1999). Two methods, namely the detection in time domain and RN, were used for the analysis of data from the experiment PASSEQ.

\section{METHODOLOGY - REAL TIME RECURRENT NEURAL NETWORK}

\subsection{The structure of the Real Time Recurrent Neural Network applied for seismic event detection}

The Real Time Recurrent Neural Network (RTRN) belongs to artificial neural networks. The structure of RTRN (Fig. 2) and the learning method were developed by Wiliams and Zipser (1989). The RTRN was used by Wiszniowski et al. (2014) for the detection of small natural earthquakes with a magnitude of 0.4 to 2.5, in the Polish part of the Western Carpathians. This is the simplest recurrent artificial neural network that operates in discrete time settings. The $i$-th artificial neuron at a moment $t$ has an output value:

$$
V_{i}(t)=\mathrm{g}\left(\sum_{j=0}^{n-1} w_{i j} v_{j}(t)\right)
$$




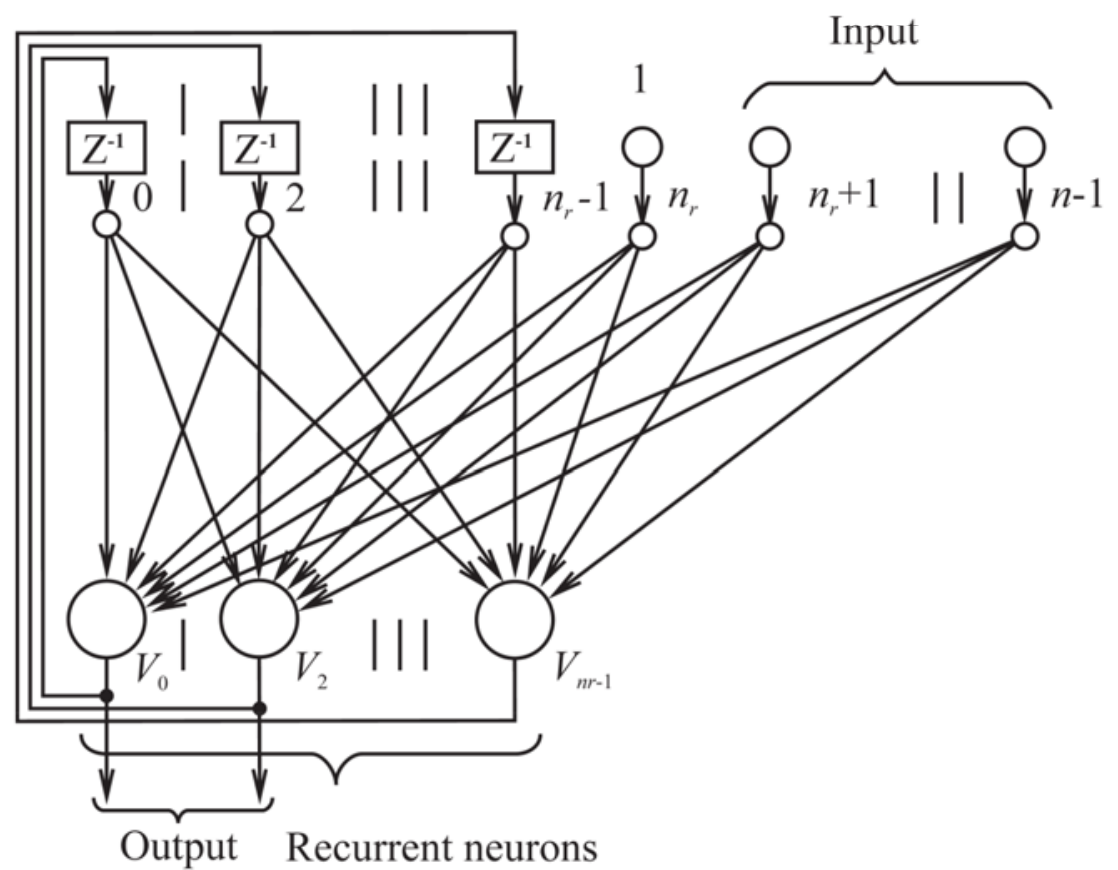

Fig. 2. The model of the RTRN network applied to the detection of small natural earthquakes in Poland. It contains $\mathrm{nr}$ recurrent neurons. Outputs of neurons $V_{0}, V_{1}$, and $V_{2}$ are outputs of the network. They corresponded to: detection of event $\left(V_{0}\right)$, detection of phase $P\left(V_{1}\right)$ onset, and detection of phase $S\left(V_{2}\right)$ onset. Inputs from $n_{r}+1$ to $n-1$ are inputs of the network, whereas input nr has a constant value 1 (bias). [Z 1] is a delay element with a delay of one step of the network work. RTRN used for detection in PASSEQ has 26 inputs and 16 recurrent neurons. Therefore, each neuron has $n=43$ inputs.

where $\mathrm{g}($.$) is an activation function, w_{i j}$ are weight coefficients between inputs and the output of the neuron, $v_{j}(t)$ are input values:

$$
v_{j}(t)=\left\{\begin{array}{lll}
V_{j}(t-1) & j=0, \ldots, n_{r}-1 & \text { recurrent neurons } \\
1 & j=n_{r} & \text { constant value egual 1 } \\
x_{i}(t) & j=n_{r}+i ; i=1, \ldots, k & \text { inputs of the RTRN }
\end{array}\right.
$$

$V_{j}(t)$ are output values of neurons, $x_{i}(t)$ are input values of the RTRN, $k$ is the number of input neurons, and $n=n_{r}+k+1$ is the number of inputs of neurons. 
RTRN consists of recurrent neurons whose outputs are recurrently connected to their own inputs (Fig. 2). The return signals from recurrent neurons are put to inputs with a delay of one network time step. The purpose of RTRN is to discriminate the seismic events from noise (disturbances), aiming to detect a maximum number of small earthquakes, whose amplitudes are below the noise level, and to produce an acceptable number of false detections. Outputs of the first three recurrent neurons were also outputs of the network and they corresponded to: detection of event $\left(V_{0}\right)$, detection of phase $P\left(V_{1}\right)$ onset and detection of phase $S\left(V_{2}\right)$ onset. Only the output $V_{0}$ was taken into consideration for the events detection. Outputs $V_{1}$ and $V_{2}$, which correspond to $P$ and $S$ waves, are used only during the ANN training.

The data for training the RTRN consists of a section referring to seismic events and another section concerning seismic noise, mainly due to human activity. The training method relies on corrections made to weight coefficients to minimize the discrepancy between real and expected neural network output value according to the formula:

$$
\Delta w_{p q}=-\alpha \frac{\partial E(t)}{\partial w_{p q}}
$$

where $\alpha$ is a learning rate and the function $E$ is defined as:

$$
E(t)=\sum_{i=0}^{2} \eta_{i}(t)\left[\zeta_{i}(t)-o_{i}(t)\right]^{2}
$$

where $\zeta_{i}$ is the expected output of $i$-th neuron, $\eta_{i}$ is a learning coefficient and $o_{i}$ is the real output of the RTRN, $i=0,1,2$. Both $\zeta$ and $\eta$ depend on the phases of the seismic event. The values of the expected output of network were:

$\zeta_{0}$ (event detection): -1 for noise, +1 for a seismic event from the first phase to a few seconds after the signal reached the level of noise,

$\zeta_{1}$ (phase $P$ ): -1 before the onset of the phase, +1 from the beginning of the phase to a few seconds after the end of the $P$ coda, but not less than to the beginning of the phase $S$,

$\zeta_{2}$ (phase $S$ ): -1 before the onset of the phase, +1 from the beginning of the phase to a few seconds after the end of the $S$ coda.

The values of learning coefficients vary according to the formulas (Wiszniowski et al. 2014):

$$
\begin{aligned}
& \eta_{0}(t)=0 \\
& \eta_{0}(t)=1 \\
& \eta_{0}(t)=0.001 \\
& \eta_{0}(t)=1 \\
& \begin{array}{l}
; t \in\left(T_{0}, T_{0}+300\right), \\
; t \in\left(T_{0}+300, T_{P}\right), \\
; t \in\left(T_{P}, T_{S}\right) \text { or } t \in\left(T_{P}, T_{P}+5\right), \\
; t \in\left(T_{S}, T_{S}+10\right),
\end{array}
\end{aligned}
$$




$$
\begin{array}{ll}
\eta_{0}(t)=\mathrm{e}^{T S-t+10} & ; t>T_{S}+10, \\
\eta_{1}(t)=0 & ; t \in\left(T_{0}, T_{0}+300\right), \\
\eta_{1}(t)=1 & ; t \in\left(T_{0}+300, T_{S}+1\right), \\
\eta_{1}(t)=\mathrm{e}^{T S-t+1} & ; t>T_{S}+1, \\
\eta_{2}(t)=0 & ; t \in\left(T_{0}, T_{0}+300\right), \\
\eta_{2}(t)=1 & ; t \in\left(T_{0}+300, T_{S}+10\right), \\
\eta_{2}(t)=\mathrm{e}^{T S-t+10} & ; t>T_{S}+10,
\end{array}
$$

where $T_{P}$ and $T_{S}$ are times of phases. The $T_{0}$ is the time of the beginning of each training record. The value of the learning coefficients is zero after the $T_{0}$, because output values of neurons are initially set to zero and neurons need a few time steps to reach their typical operating values.

Preparation of the training data for RTRN was difficult, because of a lack of recordings of local events in the study area. To do this, the seismic records from the Monitoring of Seismic Hazard of the Territory of Poland (MSHTP) project were investigated (Trojanowski et al. 2015). Records from 5 days (15-19 January 2009) were analyzed, 170 earthquakes (local - induced in Legnica-Glogow Copper District (LGCD) and the Upper Silesia Coal Basin (USCB), natural from the Podhale region, regional and teleseismic) and about 9000 noises were identified. On this basis, two training sets were prepared - one with seismic events and the other with noises. Parallel computation with the use of OpenMP library was applied to speed up the calculations. 10-fold parallelism on a 16-core computer was obtained. Two methods were used for learning the neural network: real time recurrent learning (Wiliams and Zipser 1989) and back propagation throough time (Werbos 1990).

The RTRN, which was used in MSHTP project, relied on wide range of frequencies of a recorded signal to resolve noise, characterized with, for example, higher frequencies. All stations recorded the seismic signal in a frequency band of 1-40 Hz. The sampling frequency was $100 \mathrm{~Hz}$. Besides, the noise level was lower than in the PASSEQ experiment. Therefore, the RTRN analyzing of only the vertical signal in the MSHTP project was good enough for detection (hereinafter referred to as RTRN1D). In case of the PASSEQ project, the stations were recorded in different a frequency band, mainly depending on the sampling frequency. The lowest sampling frequency used was $20 \mathrm{~Hz}$. This means that maximum registered frequency in all PASSEQ seismic stations was $8 \mathrm{~Hz}$. It resulted in a substantial limitation of the signal information provided to the detection algorithm. Especially, high frequency noises are worse discriminated from seismic waves. To compensate for the limitation of the detection of low frequency data, the vertical signal components were used. This allows for the use of information, such as the polariza- 
tion of the signal. This solution was prepared for the Podhale data in MSHTP, but it was not applied because of the sufficient effectiveness of the RTRN1D. The new RTRN with three dimensional inputs data (RTRN3D) was extended to process horizontal data. Now, it consists of 16 recurrent neurons and 26 input neurons. The first 11 inputs are supplied with the ratio of short-term averages (STAs) and long term averages (LTAs) of the filter bank of horizontal components of the signal. The filter bank filters the signal in different frequency ranges at the width of $1 / 3$ octave. It consists of 11 filters with a middle frequency in the range of 0.6 to $8 \mathrm{~Hz}$ (Fig. 3a). The RTRN3D has less vertical inputs than the RTRN1D, which had 15 inputs, because of a shorter frequency band. The next 11 inputs of the RTRN3D are supplied with the ratio of STAs and LTAs of a root mean square of vertical components of the signal filtered by the same filter bank.

The result of training the RTRN1D shows the quick forgetfulness of a recurrent network. Especially, in the case of regional events, the information of the $P$ wave is forgotten when the $S$ wave enters. Therefore, to gain more information on time dependencies of the signal, the last 4 inputs are supplied with the signals shifted 18 seconds in time - predating the main signal. The signal is also filtered, but by a smaller number of filters in a wider range
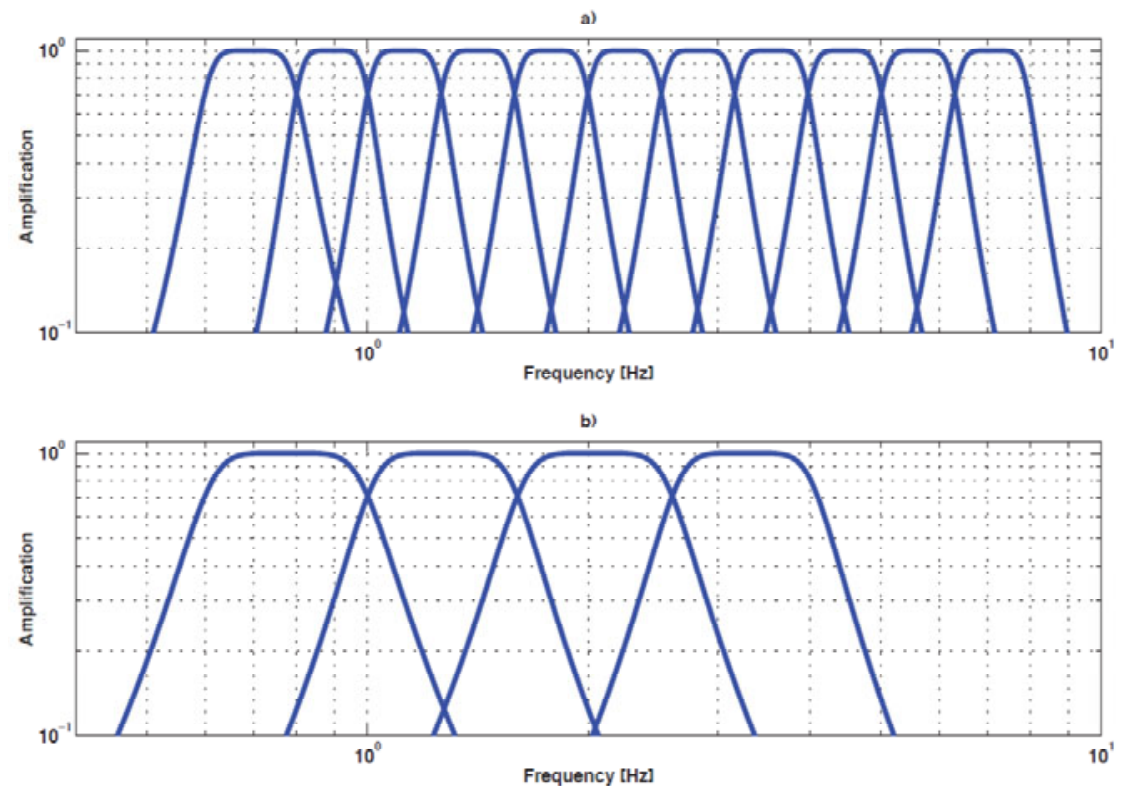

Fig. 3. Amplitude-frequency characteristics of input signals from horizontal and vertical components for RTRN3D detection: (a) filter bank for horizontal and vertical components, (b) filter bank for vertical components supplied to the input of RTRN3D in $18 \mathrm{~s}$ advance. 
(Fig. 3b). Thanks to shifting the data in time, the future information is available earlier, before the current information is forgotten.

\subsection{RTRN3D detection method for local seismic events in Poland based on data from THE PASSEQ project}

Data recorded during the PASSEQ 2006-2008 project by seismic stations placed in a radius of $100 \mathrm{~km}$ around the town of Jarocin (17 seismic stations, Table 1), was analyzed with the RTRN3D network. The region of Jarocin was selected due to the seismic activity discovered in this region in 2012 (Lizurek et al. 2013). The output $V_{0}$ of the RTRN3D was taken into consideration for the events detection (Figs. 4 and 5). The detection threshold was set at the level of 0.3 . After voting on a least 3 stations, we obtained 3854

Table 1

List of seismic stations of the PASSEQ project from the Jarocin region on which the RTRN3D detection was applied

\begin{tabular}{|c|c|c|c|c|c|}
\hline No. & Station & Place & $\begin{array}{c}\text { Latitude } \\
{\left[{ }^{\circ} \mathrm{N}\right]}\end{array}$ & $\begin{array}{c}\text { Longitude } \\
{\left[{ }^{\circ} \mathrm{E}\right]}\end{array}$ & Recording period \\
\hline 1 & A66 & raby, Poland & 52.4092 & 17.4722 & 26.07.2006-18.11.2007 \\
\hline 2 & & & & & 26.07.2006-16.05.2007 \\
\hline 3 & & singer, & & & 11.09 \\
\hline 4 & & anikowt & & & \\
\hline 5 & 347 & esłabin, $\mathrm{Pc}$ & 52.1 & & 16.05 .2 \\
\hline 6 & & & 52.2849 & 17.3 & 27.07 \\
\hline 7 & & wie & 52.4 & & 16.05 \\
\hline 8 & 350 & ien & 52.5738 & 18. & 27.07 \\
\hline 9 & PD43 & $\begin{array}{l}\text { Zygmuntowo, } \\
\text { Poland }\end{array}$ & 51.6553 & 17.2284 & 28.07.2006-26.06.2008 \\
\hline 10 & PD44 & & & & 25.07 \\
\hline 11 & & & & & 08.07 \\
\hline 12 & & & & & 08.0 \\
\hline 13 & & & & & 09.07 . \\
\hline 14 & PG43 & Świerki, Poland & 51.4720 & 18.7240 & 08.07.2006-27.05.2008 \\
\hline 15 & PN42 & Buków, Poland & 52.1417 & 15.6283 & $\begin{array}{l}05.07 .2006-27.03 .2007 \\
15.05 .2007-23.06 .2008\end{array}$ \\
\hline 16 & PN43 & & 52.4581 & 16.4361 & 05.05.2007-23.06.2008 \\
\hline 17 & PN44 & $\begin{array}{l}\text { Łoskoń Stary, } \\
\text { Poland }\end{array}$ & 52.6603 & 17.0552 & $15.07 .2006-23.06 .2008$ \\
\hline
\end{tabular}


Table 2

Number of RTRN3D detections on the PASSEQ seismic stations from the regions near Jarocin and the Gulf of Gdańsk

\begin{tabular}{|l|c|c|}
\hline \multicolumn{1}{|c|}{ Region } & Jarocin & Gulf of Gdańsk \\
\hline Time period & $2006.07 .05-2008.06 .26$ & $2006.06 .14-2008.06 .18$ \\
Number of detection & 3854 & 6198 \\
Induced events from LGCB & $59 \%$ & $20 \%$ \\
$\quad \begin{array}{l}\text { and USCD } \\
\text { Other local and regional } \\
\text { events }\end{array}$ & $3 \%$ & $2 \%$ \\
Teleseismic events & $7 \%$ & $4 \%$ \\
Noises and disturbances & $31 \%$ & $74 \%$ \\
\hline
\end{tabular}

detections (Table 2). They included mostly local induced events from the LGCD and USCB, other local and regional events, teleseismic events, and false detections. The other local and regional events include both natural and induced events from the surrounding Polish area, as well as singular induced events from other regions in Poland, e.g., Bełchatów. Most tremors come from the LGCD ( $42 \%$ of detections). Only one earthquake from 6 May 2007, 7:32 UTC of $M_{L}=2.8$ was localized in the region of Jarocin.

Table 3

List of seismic stations of the PASSEQ project from the Gulf of Gdańsk region on which seismic records the RTRN3D detection was applied

\begin{tabular}{|c|c|c|c|c|c|}
\hline No. & Station & Place & $\begin{array}{l}\text { Latitude } \\
{\left[{ }^{\circ} \mathrm{N}\right]}\end{array}$ & $\begin{array}{c}\text { Longitude } \\
{\left[{ }^{\circ} \mathrm{E}\right]}\end{array}$ & Recording period \\
\hline 1 & PA70 & Wikno, Poland & 53.4720 & 20.5229 & $\begin{array}{c}27.07 .2006- \\
19.11 .2007\end{array}$ \\
\hline 2 & PA71 & Kołowinek, Poland & 53.7424 & 21.4321 & $\begin{array}{c}27.07 .2006- \\
28.07 .2007\end{array}$ \\
\hline 3 & PA73 & Pobondzie, Poland & 54.3191 & 22.9493 & $\begin{array}{c}28.07 .2006- \\
24.10 .2007\end{array}$ \\
\hline 4 & PB57 & Sasek, Poland & 53.6294 & 20.9086 & $\begin{array}{c}04.10 .2006- \\
04.06 .2008\end{array}$ \\
\hline
\end{tabular}


Table 3 (continuation)

\begin{tabular}{|c|c|c|c|c|c|}
\hline No. & Station & Place & $\begin{array}{l}\text { Latitude } \\
{\left[{ }^{\circ} \mathrm{N}\right]}\end{array}$ & $\begin{array}{c}\text { Longitude } \\
{\left[{ }^{\circ} \mathrm{E}\right]}\end{array}$ & Recording period \\
\hline 5 & PB59 & Grabówka, Poland & 53.8226 & 21.7022 & $\begin{array}{l}29.06 .2006- \\
24.12 .2007\end{array}$ \\
\hline 6 & PB60 & Siemionki, Poland & 53.9503 & 22.0117 & $\begin{array}{c}29.06 .2006- \\
06.11 .2007\end{array}$ \\
\hline 7 & PB61 & Garbaś, Poland & 54.1635 & 22.5941 & $\begin{array}{c}29.06 .2006- \\
16.01 .2008\end{array}$ \\
\hline 8 & PD81 & Paliepis, Lithuania & 54.0056 & 23.7865 & $\begin{array}{l}17.06 .2006- \\
04.09 .2007\end{array}$ \\
\hline 9 & PN47 & $\begin{array}{l}\text { Świecie nad Osa, } \\
\text { Poland }\end{array}$ & 53.4519 & 19.0899 & $\begin{array}{l}18.07 .2006- \\
03.06 .2008\end{array}$ \\
\hline 10 & PN48 & Sapy, Poland & 53.7092 & 19.6750 & $\begin{array}{c}18.07 .2006- \\
04.06 .2008\end{array}$ \\
\hline 11 & PN49 & Sętal, Poland & 53.9103 & 20.4865 & $\begin{array}{l}19.07 .2006- \\
04.06 .2008\end{array}$ \\
\hline 12 & PP45 & Cisowa Góra, Poland & 53.7445 & 18.5186 & $\begin{array}{c}18.07 .2006- \\
18.06 .2008\end{array}$ \\
\hline 13 & PP46 & Chartowo, Poland & 53.9930 & 19.2812 & $\begin{array}{c}18.07 .2006- \\
04.06 .2008\end{array}$ \\
\hline 14 & PP47 & Kiersiny, Poland & 54.2879 & 20.0599 & $\begin{array}{c}19.07 .2006- \\
12.05 .2008\end{array}$ \\
\hline 15 & PP82 & Paliepai, Lithuania & 55.3525 & 23.5543 & $\begin{array}{c}15.06 .2006- \\
10.01 .2008\end{array}$ \\
\hline 16 & PP83 & Ustronè, Lithuania & 55.6155 & 24.1015 & $\begin{array}{l}16.06 .2006- \\
09.01 .2008\end{array}$ \\
\hline 17 & PR46 & Trzebun, Poland & 54.0194 & 17.7060 & $\begin{array}{c}16.07 .2007- \\
18.06 .2008\end{array}$ \\
\hline 18 & PR81 & Lašinskiai, Lithuania & 55.6588 & 22.8915 & $\begin{array}{c}14.06 .2006- \\
09.01 .2008\end{array}$ \\
\hline 19 & PR82 & Narteikai, Lithuania & 56.0482 & 24.1764 & $\begin{array}{c}15.06 .2006- \\
09.01 .2008\end{array}$ \\
\hline 20 & PQ50 & Jasiowa Huta, Poland & 54.1781 & 18.1912 & $\begin{array}{c}04.08 .2006- \\
08.10 .2006\end{array}$ \\
\hline 21 & PQ81 & Radvietis, Lithuania & 55.5111 & 21.9334 & $\begin{array}{l}02.11 .2006- \\
22.09 .2007\end{array}$ \\
\hline 22 & PQ82 & Jaugèlai, Lithuania & 55.7658 & 23.4980 & $\begin{array}{l}03.11 .2006- \\
22.09 .2007\end{array}$ \\
\hline 23 & PT81 & Žarėnai, Lithuania & 55.8361 & 22.2079 & $\begin{array}{l}14.06 .2006- \\
02.10 .2007\end{array}$ \\
\hline
\end{tabular}



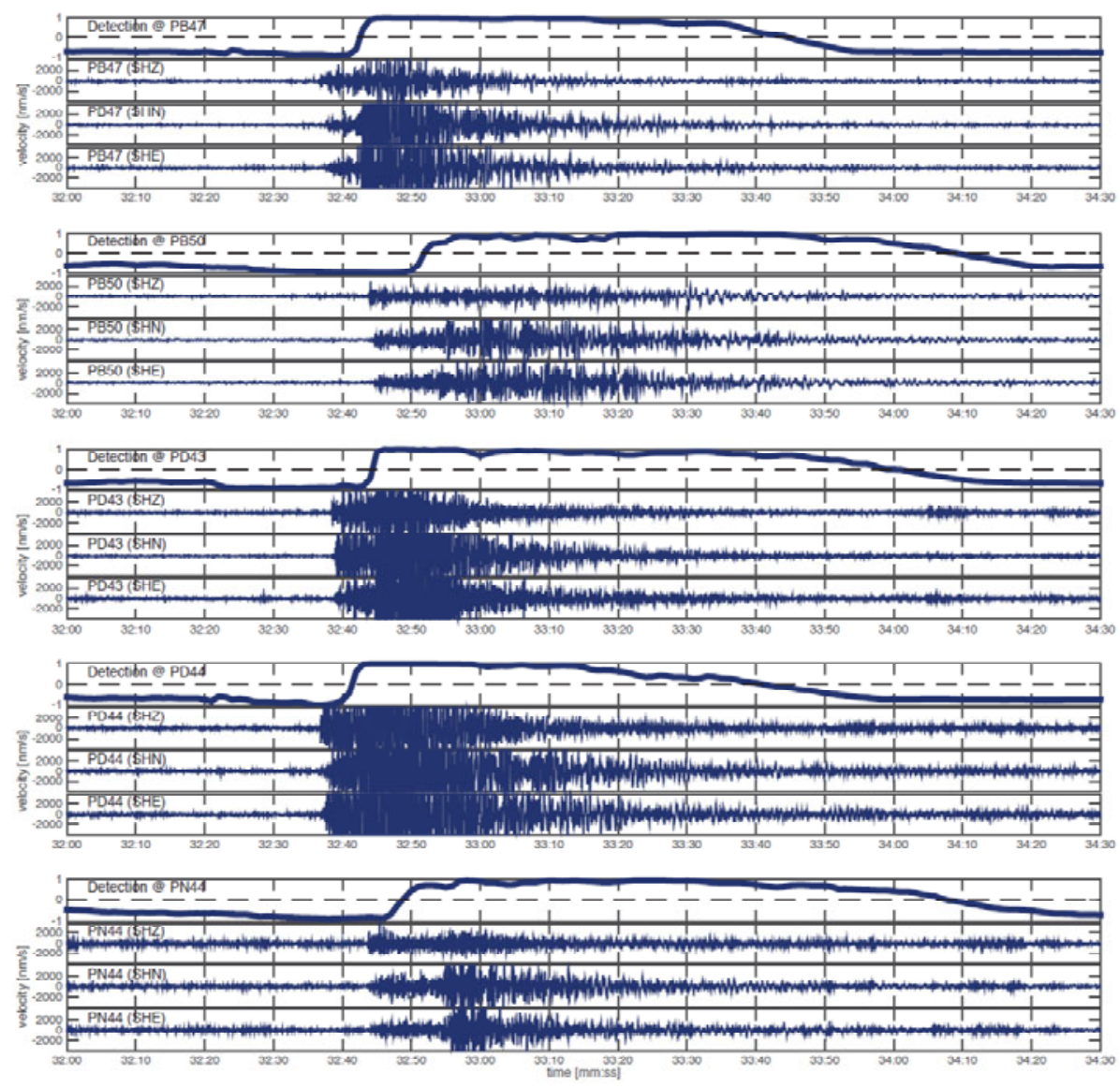

Fig. 4. Example of records and RTRN3D detection - the earthquake of 6 May 2007, 7:32 UTC $M_{L}=2.8$ occurred near Jarocin: PB47, PB50, PD43, PD44, and PN44 seismic stations; the signals on top of the records are $V_{0}$ (event detection) outputs of RTRN3D.

Figures 4 and 5 show examples of seismograms and RTRN3D network detections of events recorded by PASSEQ seismic stations.

The second region, which was analyzed with the RTRN3D network, was the Gulf of Gdańsk and its neighborhood (23 seismic stations, Table 3). Records from the PASSEQ stations situated within a radius of about $250 \mathrm{~km}$ from the shore, including stations located in Poland and Lithuania, were analyzed. The result consisted in 6198 detections (Table 2). They included mostly false detections, generated by sea noise, as well as teleseismic events and regional seismic events from Poland. 


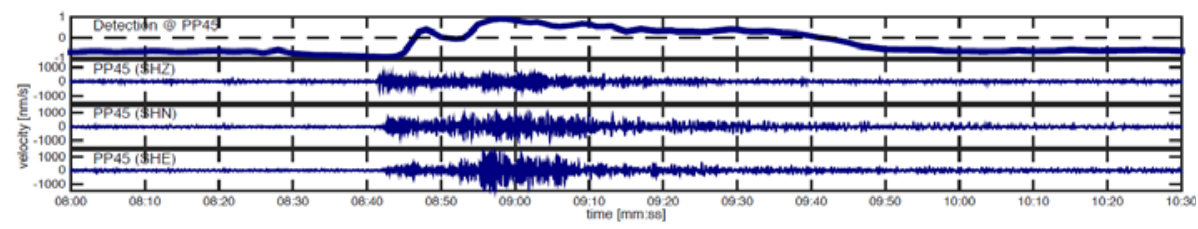

Fig. 5. Output of detection of the RTRN3D (detpp45) together with seismic signal of PASSEQ station PP45 for 2 May 2007 event in the Gulf of Gdańsk area. It is seen that both $P$ and $S$ waves are used for event detection.

\section{METHODOLOGY - STA/LTA DETECTION METHOD}

\subsection{Detection of seismic signals}

A detection goal was to analyze the continuous time series (seismic record) and provide a list of moments where the possible signal (seismic wave) was recorded. The analysis was done after the PASSEQ experiment had ended, so the methods were customized for analyzing large portions of data. The main python function was prepared to return a list of signal detections for a given file name (already prepared one-hour, one station, one component miniseed file). Most of the continuous data analysis and detection were done using ObsPy software (Beyreuther et al. 2010, Megies et al. 2011).

The analysis was carried out in three steps: data loading, filtration and detection of the signal. The data was filtered with a zero-phase bandpass Butterworth filter (from 4.0 to $9.5 \mathrm{~Hz}$ ). After filtration, the mean value of the trace was removed and the amplitude normalized to a constant value (the same value for all stations). An example of the filtration of the broadband trace is shown in Fig. 6. A detector has to adapt to current conditions (e.g., noise level). The simplest way to create such a detector is calculating two moving averages over a signal with different windows: short and long. Most of the seismic detectors use a relation between the short-term average (STA) and long term average (LTA) (Withers et al. 1998, Trnkoczy 2012). In this paper, Carl Johnson's STA/LTA detection algorithm was used (Johnson 1979). This algorithm calculates four moving averages and takes two parameters:

$$
\text { eta }=\text { star }-(\text { ratio } * \text { ltar })-a b s(\text { sta }-l \text { lta })-\text { quiet }
$$

where: eta is the detector response - a value over 0 means detection, sta is the short term moving average of signal, lta is the long term moving average of signal, star is the short term moving average of absolute value of signal and lta difference, ltar is the long term moving average of star, ratio, and quiet-sensitivity parameters. Short term average had a 4-second window and 

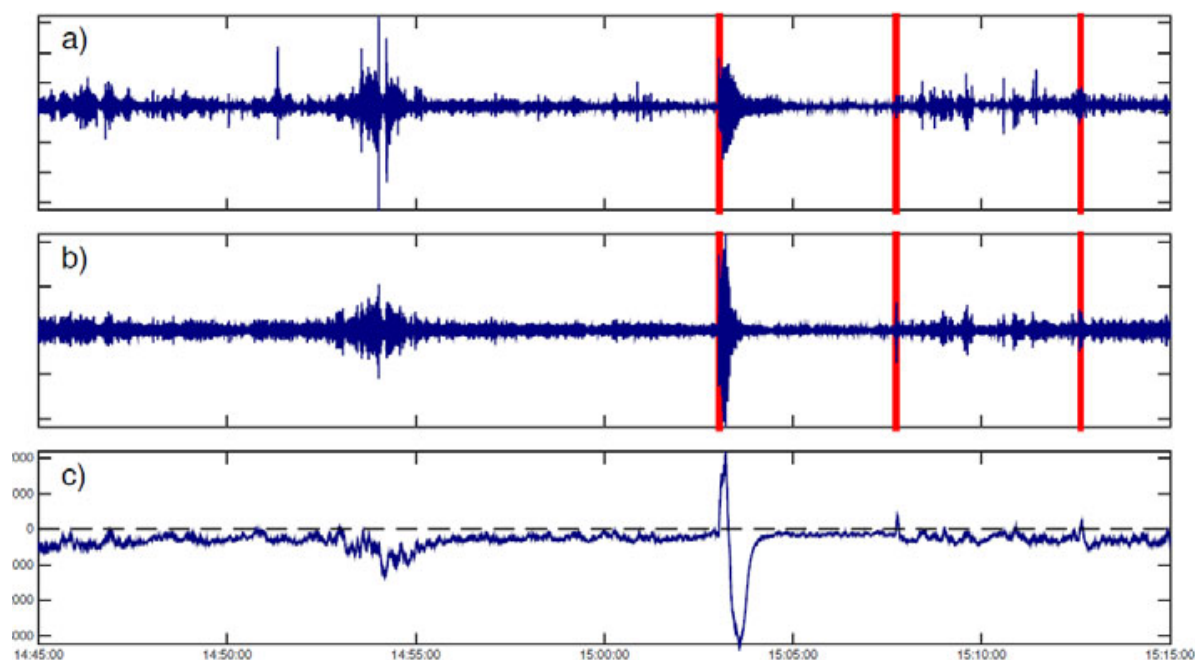

Fig. 6: (a) Example of 30-minute recording (vertical component) from station PA64 recorded on 24 August 2006. Thick red lines indicate the trigger result. (b) Same example filtered with bandpass filter from 4.5 to $9 \mathrm{~Hz}$. (c) Trigger response: values over 0 for longer than 0.1 seconds are taken as a positive trigger and marked thick red lines.

long term average had a 32-second window. Both ratio and quiet parameters had value 2. Example result is shown in Fig. 6.

\subsection{Analysis of coinciding detections - grid search method}

The detector responds to seismic waves together with noise signals. An additional analysis of detection signals is required to recognize local seismic events. To analyze coinciding detections, the study area was represented as a grid with a cell size of 0.05 by 0.05 arc degrees. The analysis was done one day of recording at the time, which was optimal for the performance and number of I/O operations. An analysis of longer periods would have required more operating memory, exceeding the capacity of a standard workstation computer. A list of detections from all the stations for that day was taken with their exact time - at this point detection on the list included real seismic signals from local events, a detection of regional and teleseismic events and accidental detections of noise. In the next step, a list of detections was analyzed to check if there was a place in space and time where a seismic event might have occurred causing such a distribution of detections. This allows for reducing the number of detections not correlated with local seismicity. For each grid cell, the number of stations operating within a radius of 

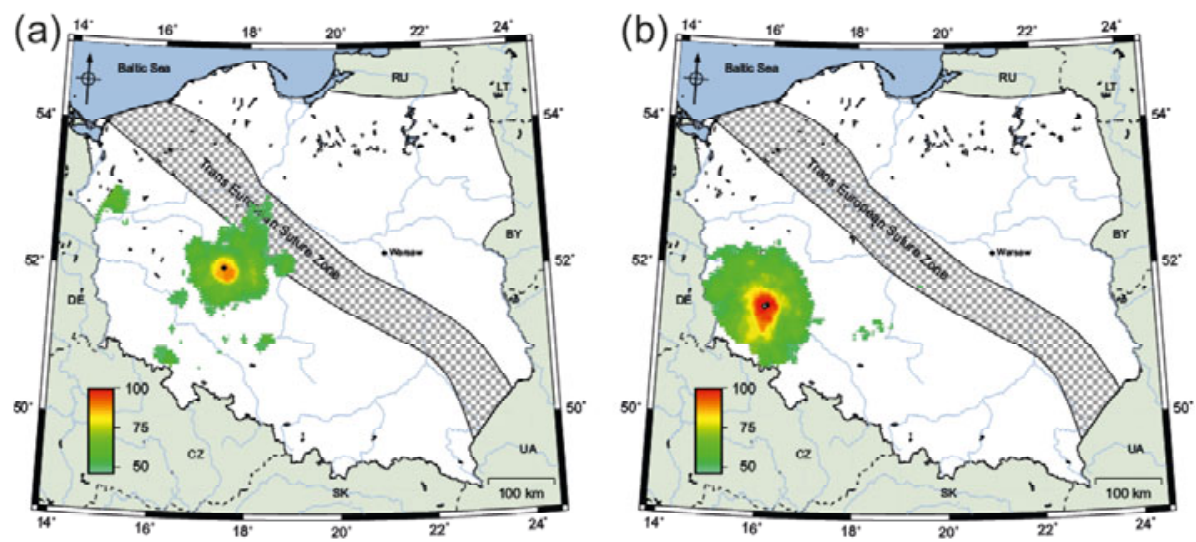

Fig. 7: (a) New seismic event on 6 May 2007 07:32:30 UTC. Color shows percent of stations in $150 \mathrm{~km}$ radius with a positive trigger. A black dot shows the estimated earthquake location. See text for more explanation. (b) Example for a known local event. The color shows the percent of stations in a $150 \mathrm{~km}$ radius with a positive trigger. A black dot shows the event epicenter from a Local Bulletin of the Institute of Geophysics, Polish Academy of Sciences, and a white dot shows the calculated epicenter.

$150 \mathrm{~km}$ was determined, and the cells with at least 15 stations working in their neighborhood were selected for the subsequent analysis. For each of the selected cells, all the detections of the surrounding stations (within the $150 \mathrm{~km}$ radius) are inspected; for each station, the $P$-wave travel time from a seismic source located in the center of the cell is computed using the 1-D reference iasp'91 model (Kennett and Engdahl 1991, Crotwell and Owens 1999); then, for each particular station detection, the origin time of a corresponding hypothetical event located in the center of the cell is estimated. The hypothetical events identified by more than $50 \%$ of the surrounding stations are kept as candidates for real events (differences up to 3 seconds between the origin times provided by individual stations are accepted). This analysis allows us to produce - for each second of studied time period - maps illustrating the probability of a seismic event location; to each cell of the study area, we assign the percentage of (surrounding) stations that identified, at the particular time moment, a seismic event in the center of the cell. Examples of grid search results are shown in Fig. 7 - for the previously known and new local events. Event localization was calculated as a weighted average of locations of grid cells with a probability of over $50 \%$. The value of probability was used as a weight in the averaging process. Figure 8 shows a histogram of the event location accuracy: the difference between the bulletin and grid search location for all 53 events in the LGCB that occurred from 1 August 


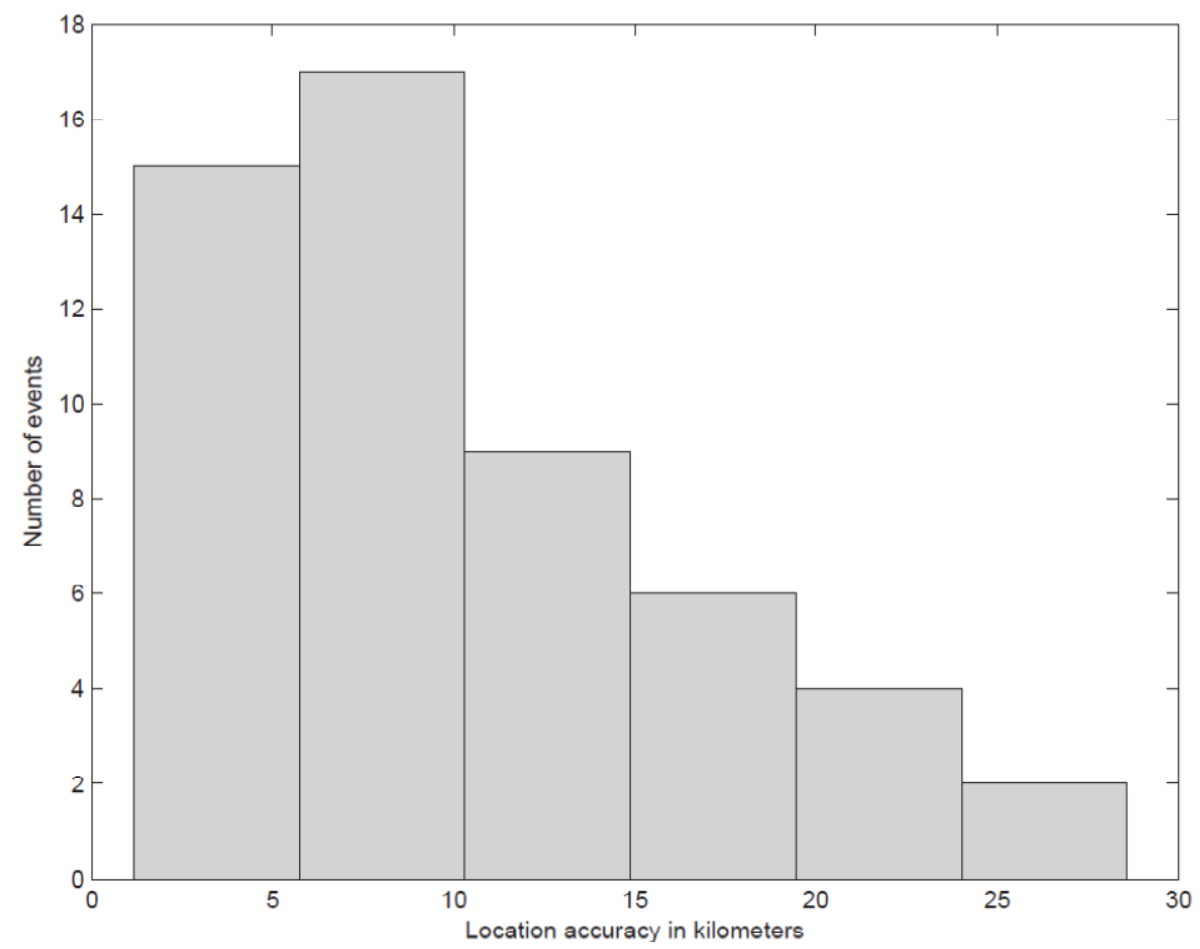

Fig. 8. Histogram of event location accuracy (difference between bulletin and grid search location). Total of 53 events in the LGCB were analyzed from 1 August 2006 to 31 October 2006.

2006 to 31 October 2006. On average, the location accuracy is better than $15 \mathrm{~km}$, however this analysis is not entirely correct due to the unknown event location quality in the bulletin, which is based on fewer seismic stations than available during PASSEQ. The detection accuracy could be improved by use of a more detailed seismic wave velocity model for the studied area (Grad and Polkowski 2012, Polkowski and Grad 2015). The advantage of the grid search method is its ability to detect multiple seismic events occurring at the same time in different parts of the study area.

\subsection{Application of STA/LTA for PASSEQ data}

After analyzing the whole PASSEQ 2006-2008 data set for Poland, over 3500 events were automatically detected. This list was then filtered to eliminate noise-only detections. Filtration was done by eliminating the events visible in less than 20 grid cells. 
The new list consisted of 1206 events. Events in the areas of the LGCD and the USCB were not analyzed due to the known high level of the seismicity in these zones. These events were used for determining the method accuracy (detection and location). Only 46 events from other areas of Poland were on the list and have been manually analyzed: 30 events were accidental detections from known regional and teleseismic events, 12 were accidental coincidences of noise and 4 were newly localized seismic events: one in central Poland, and three in the Gulf of Gdansk.

\section{RESULTS}

Both the 3D RTRN and STA/LTA methods provided similar results. 3D RTRN detected two additional events in the Gulf of Gdańsk. Detection of these events was difficult, because of the station distribution only to the south of the Gulf of Gdańsk. Table 4 presents statistics of RTRN3D detections on PASSEQ data. LocSAT application with the IASP91 travel-time tables provides estimates of the origin time, epicentral location, and the depth from an iterative least-squares inversion of travel time, slowness, and/or azimuth (Bratt and Bache 1988, Bratt and Nagy 1991). The result of analysis of detections of STA/LTA in the area of Poland, except in the areas of known seismicity (the LGCD and the USCB), is 4 local seismic events, which are presented in Table 4. STA/LTA with grid search provided information only on the origin time and location of the event epicenter (and not

Table 4

Local earthquakes in Poland, detected using the records of the PASSEQ project

\begin{tabular}{|c|c|c|c|c|c|c|c|c|c|}
\hline \multirow{2}{*}{ No. } & \multirow{2}{*}{$M_{L}$} & \multicolumn{4}{|c|}{ STA/LTA method } & \multicolumn{5}{c|}{ RTRN3D method } \\
\cline { 2 - 10 } & $\begin{array}{c}\text { Time } \\
{[\mathrm{UTC}]}\end{array}$ & $\begin{array}{c}\text { Latitude } \\
{\left[{ }^{\circ} \mathrm{N}\right]}\end{array}$ & $\begin{array}{c}\text { Longitude } \\
{\left[{ }^{\circ} \mathrm{E}\right]}\end{array}$ & $\begin{array}{c}\text { Depth } \\
{[\mathrm{km}]}\end{array}$ & $\begin{array}{c}\text { Time } \\
{[\mathrm{UTC}]}\end{array}$ & $\begin{array}{c}\text { Latitude } \\
{\left[{ }^{\circ} \mathrm{N}\right]}\end{array}$ & $\begin{array}{c}\text { Longitude } \\
{\left[{ }^{\circ} \mathrm{E}\right]}\end{array}$ & $\begin{array}{c}\text { Depth } \\
{[\mathrm{km}]}\end{array}$ \\
\hline A & 2.3 & - & - & - & - & $\begin{array}{c}2007-06-14 \\
00: 10: 10\end{array}$ & 54.48 & 18.99 & 10 \\
\hline B & 3.0 & $\begin{array}{c}2007-03-10 \\
23: 08: 51\end{array}$ & 54.60 & 18.75 & - & $\begin{array}{c}2007-03-20 \\
23: 08: 51\end{array}$ & 54.62 & 18.73 & 4 \\
\hline C & 3.2 & $\begin{array}{c}2007-05-02 \\
07: 08: 23\end{array}$ & 54.69 & 19.17 & - & $\begin{array}{c}2007-05-02 \\
07: 08: 23\end{array}$ & 54.72 & 19.14 & 10 \\
\hline D & - & $\begin{array}{c}2006-09-12 \\
15: 12: 14\end{array}$ & 54.55 & 19.32 & - & $\begin{array}{c}2006-09-12 \\
15: 12: 14\end{array}$ & - & - & - \\
\hline E & 2.6 & - & - & - & - & $\begin{array}{c}2007-05-22 \\
16: 29: 30\end{array}$ & 54.85 & 19.82 & 12 \\
\hline F & 2.8 & $\begin{array}{c}2007-05-06 \\
07: 32: 30\end{array}$ & 52.02 & 17.48 & - & $\begin{array}{c}2007-05-06 \\
07: 32: 31\end{array}$ & 52.01 & 17.50 & 4 \\
\hline
\end{tabular}


on the event depth and magnitude). The localization of all events from the Gulf of Gdańsk is shown on the map in Fig. 9. The localization of the event near Jarocin is shown on the map in Fig. 7a.

The event near Jarocin in central Poland (6 May 2007 07:32:30 UTC) was a natural, tectonic seismic event. In the same area, a bigger seismic event (M3.8) occurred on 6 January 2012 at 15:37:56 UTC (Lizurek et al. 2012).

The origin of events in the Gulf of Gdańsk is disputable. While in this area natural earthquakes have occurred in the past (Meyer and Kulhanek 1980, Wiejacz et al. 2001, Wiejacz 2006), the Gulf of Gdańsk is also used by the Polish Navy for destroying old explosives from the Second World War. The navy operation is confidential and we were unable to fully confirm if the detected events were or were not a result of military activity. The data quality and distribution of stations does not allow us to confirm the origin of those events. Additionally, in March and April 2015 the Polish Navy has destroyed newly discovered mines in the Gulf of Gdańsk. Seismic waves from these explosions were recorded on the stations of the "13 BB star" experiment located in northern Poland (Grad et al. 2015).

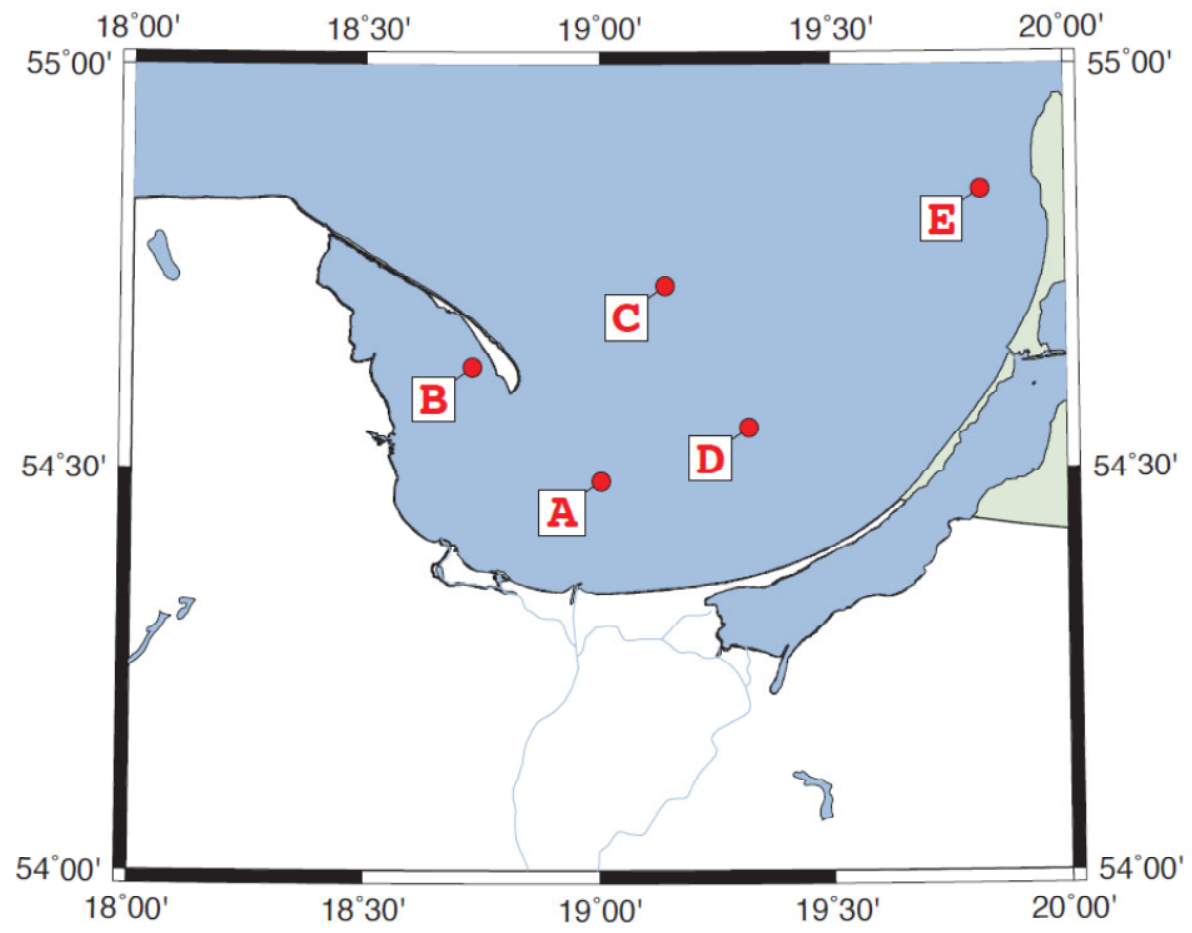

Fig. 9. Location of events in the Gulf of Gdańsk region detected with LTA/STA and RTRN3D methods. 
Acknowledgments. The public domain GMT software (Wessel et al. 2013) has been used to produce maps. The Polish Seismological Network provided data from permanent broadband stations. We also would like to thank Professor Timo Tiira for his advice.

We also would like to thank the members of PASSEQ Working Group: Monika Wilde-Piórko, Wolfram H. Geissler, Jaroslava Plomerová, Marek Grad, Vladislav Babuška, Ewald Brückl, Jolanta Cyziene, Wojciech Czuba, Richard England, Edward Gaczyński, Renata Gazdova, Soren Gregersen, Aleksander Guterch, Winfried Hanka, Endre Hegedüs, Barbara Heuer, Petr Jedlička, Jurga Lazauskiene, G. Randy Keller, Rainer Kind, Klaus Klinge, Petr Kolinsky, Kari Komminaho, Elena Kozlovskaya, Frank Krüger, Tine Larsen, Mariusz Majdański, Jiří Malek, Gediminas Motuza, Oldřich Novotný, Robert Pietrasiak, Thomas Plenefisch, Bohuslav Růžek, Saulius Sliaupa, Piotr Środa, Marzena Świeczak, Timo Tiira, Peter Voss, and Paweł Wiejacz for they support and cooperation.

This work was partially supported within statutory activities No. 3841/E41/S/2015 of the Ministry of Science and Higher Education of Poland. The National Science Centre Poland provided financial support for this work via an NCN grant DEC-2011/02/A/ST10/00284.

\section{References}

Allen, R. (1978), Automatic earthquake recognition and timing from single traces, Bull. Seismol. Soc. Am. 68, 5, 1521-1532.

Allen, R. (1982), Automatic phase pickers: their present use and future prospects, Bull. Seismol. Soc. Am. 72, 6B, S225-S242.

Beyreuther, M., R. Barsch, L. Krischer, T. Megies, Y. Behr, and J. Wassermann (2010), ObsPy: A Python toolbox for seismology, SRL 81, 530-533, DOI: 10.1785/gssrl.81.3.530.

Bratt, S.R., and T.C. Bache (1988), Locating events with a sparse network of regional arrays, Bull. Seismol. Soc. Am. 78, 2, 780-798.

Bratt, S.R., and W. Nagy (1991), The LocSAT Program, Science Applications International Corporation.

Crotwell, H.P., T.J. Owens, and J. Ritsema (1999), The taup toolkit: Flexible seismic travel-time and ray-path utilities, Seismol. Res. Lett. 70, 154-160, DOI: 10.1785/gssrl.70.2.154.

Ebel, J. (1996), Development of a seismic event detection and identification algorithm based on wavelet transforms, Seismol. Res. Lett. 67, 1-37.

Elman, J.L. (1990), Finding structure in time, Cognitive Sci. 14, 2, 179-211, DOI: 10.1016/0364-0213(90)90002-E. 
Evans, J., and S. Allen (1983), A teleseismic-specific detection algorithm for single short period traces, Bull. Seismol. Soc. Am. 73, 4, 1173-1186.

Gentili, S., and A. Michelini (2006), Automatic picking of $\mathrm{P}$ and S phases using a neural tree, J. Seismol. 10, 1, 39-63, DOI: 10.1007/s10950-006-2296-6.

Gledhill, K.R. (1985), An earthquake detector employing frequency domain techniques, Bull. Seismol. Soc. Am. 75, 6, 1827-1835.

Goforth, T., and E. Herrin (1981), An automatic seismic signal detection algorithm based on the Walsh transform, Bull. Seismol. Soc. Am. 71, 4, 1351-1360.

Grad, M., and M. Polkowski (2012), Seismic wave velocities in the sedimentary cover of Poland: Borehole data compilation, Acta Geophys. 60, 4, 9581006, DOI: 10.2478/s11600-012-0022-z.

Grad, M., T. Tiira, and ESC Working Group (2009), The Moho depth map of the European Plate, Geophys. J. Int. 176, 1, 279-292, DOI: 10.1111/j.1365246X.2008.03919.x.

Grad, M., M. Polkowski, M. Wilde-Piórko, J. Suchcicki, and T. Arant (2015), Passive Seismic Experiment "13 BB Star" in the Margin of the East European Craton, Northern Poland, Acta Geophys. 63, 2, 352-373, DOI: 10.1515/ acgeo-2015-0006.

Johnson, C.E. (1979), CEDAR: An approach to the computer automation of shortperiod local seismic networks, Ph.D. Thesis, California Institute of Technology, Pasadena, USA.

Joswig, M. (1990), Pattern recognition for earthquake detection, Bull. Seismol. Soc. Am. 80, 1, 170-186.

Joswig, M. (1993), Single-trace detection and array-wide coincidence association of local earthquakes and explosions, Comput. Geosci. 19, 2, 207-221, DOI: 10.1016/0098-3004(93)90119-P.

Kennett, B.L.N., and E.R. Engdahl (1991), Traveltimes for global earthquake location and phase identification, Geophys. J. Int. 105, 2, 429-465, DOI: 10.1111/j.1365-246X.1991.tb06724.x.

Lizurek, G., B. Plesiewicz, P. Wiejacz, J. Wiszniowski, and J. Trojanowski (2013), Seismic event near Jarocin (Poland), Acta Geophys. 61, 1, 26-36, DOI: 10.2478/s11600-012-0052-6.

Madureira, G., and A.E. Ruano (2009), A neural network seismic detector, Acta Tech. Jaurinesis 2, 2, 159-170, DOI: 10.3182/20090921-3-TR-3005.00054.

McEvilly, T.V., and E.L. Majer (1982), ASP: An automated seismic processor for microearthquake networks, Bull. Seismol. Soc. Am. 72, 1, 303-325.

Megies, T., M. Beyreuther, R. Barsch, L. Krischer, and J. Wassermann (2011), Obspy - what can it do for data centers and observatories?, Ann. Geophys. 54, 1, 47-58, DOI: 10.4401/ag-4838.

Meyer, K., and O. Kulhanek (1980), The gulf of Gdańsk seismic event sequence of June 25 - July 3, Acta Geophys. Pol. 29, 4, 315-320. 
Pharaoh, T.C. (1999), Palaeozoic terranes and their lithospheric boundaries within the trans-european suture zone (tesz): a review, Tectonophysics 314, 1-3, 17-41, DOI: 10.1016/S0040-1951(99)00235-8.

Polkowski, M., and M. Grad (2015), Seismic wave velocities in deep sediments in Poland: Borehole and refraction data compilation, Acta Geophys. 63, 698714, DOI: 10.1515/acgeo-2015-0019.

Tarvainen, M. (1991), Detection local and regional seismic events using the dataadaptive method at the VAF seismograph station in Finland, Bull. Seismol. Soc. Am. 81, 4, 1373-1379.

Tiira, T. (1999), Detecting teleseismic events using artificial neural networks, Comput. Geosci. 25, 8, 929-938, DOI: 10.1016/S0098-3004(99)00056-4.

Trnkoczy, A. (2012), Understanding and parameter setting of STA/LTA trigger algorithm, New Manual of Seismological Observatory Practice 2.

Trojanowski, J., B. Plesiewicz, and J. Wiszniowski (2015), Seismic monitoring of Poland - temporary Seismic Project with mobile Seismic Network, Acta Geophys. 63, 1, 17-44, DOI: 10.2478/s11600-014-0255-0.

Wang, J., and T.-L. Teng (1995), Artificial neural network-based seismic detector, Bull. Seismol. Soc. Am. 85, 1, 308-319.

Wang, J., and T.-L. Teng (1997), Identification and picking of S phase using an artificial neural network, Bull. Seismol. Soc. Am. 87, 5, 1140-1149.

Werbos, P. (1990), Backpropagation through time: what it does and how to do it, Proc. IEEE 78, 10, 1550-1560, DOI: 10.1109/5.58337.

Wessel, P., W.H. F. Smith, R. Scharroo, J.F. Luis, and F. Wobbe (2013), Generic Mapping Tools: Improved version released, EOS Trans. AGU 94, 45, 409410.

Wiejacz, P. (2006), The Kaliningrad earthquakes of September 21, 2004, Acta Geodyn. Geomat. 3, 7-16.

Wiejacz, P., and W. Dębski (2001), New observations of gulf of Gdansk seismic events, Phys. Earth Planet. Int. 123, 2-4, 233-245, DOI: 10.1016/S00319201(00)00212-0.

Wilde-Piórko, M., W.H. Geissler, J. Plomerová, M. Grad, V. Babuška, E. Brückl, J. Cyziene, W. Czuba, R. England, E. Gaczyński, R. Gazdova, S. Gregersen, A. Guterch, W. Hanka, E. Hegedüs, B. Heuer, P. Jedlička, J. Lazauskiene, G. Randy Keller, R. Kind, K. Klinge, P. Kolinsky, K. Komminaho, E. Kozlovskaya, F. Krüger, T. Larsen, M. Majdański, J. Málek, G. Motuza, O. Novotný, R. Pietrasiak, Th. Plenefisch, B. Růžek, S. Sliaupa, P. Środa, M. Świeczak, T. Tiira, P. Voss, and P. Wiejacz (2008), PASSEQ 2006-2008: Passive Seismic Experimentin Trans - European Suture Zone, Stud. Geophys. Geod. 52, 439-448.

Williams, R., and D. Zipser (1989), A learning algorithm for continually running fully recurrent neural networks, Neural Comput. 1, 2, 270-280, DOI: 10.1162/neco.1989.1.2.270. 
Wiszniowski, J., B. Plesiewicz, and J. Trojanowski (2014), Application of Real Time Recurrent Neural Network for detection of small natural earthquakes in Poland, Acta Geophys. 62, 3, 469-485, DOI: 10.2478/s11600-013-0140-2.

Withers, M., R. Aster, C. Young, J. Beiriger, M. Harris, S. Moore, and J. Trujillo (1998), A comparison of select trigger algorithms for automated global seismic phase and event detection, Bull. Seismol. Soc. Am. 88, 1, 95-106.

Received 22 November 2015

Received in revised from 5 April, 2016

Accepted 5 May 2016 